\title{
Hydrochemistry and its controlling factors of rivers in the source region of the Yangtze River on the Tibetan Plateau
}

\author{
Liguang Jiang ${ }^{\mathrm{a}, \mathrm{b}}$, Zhijun Yao ${ }^{\mathrm{a}, *}$, Zhaofei Liu ${ }^{\mathrm{a}}$, Rui Wang ${ }^{\mathrm{a}, \mathrm{b}}$, Shanshan $\mathrm{Wu}^{\text {a }}$ \\ a Institute of Geographic Sciences and Natural Resources Research, Chinese Academy of Sciences, 11A Datun Road, Chaoyang District, Beijing 100101, China \\ ${ }^{\mathrm{b}}$ University of Chinese Academy of Sciences, 19A Yuquan Road, Shijingshan District, Beijing 100049, China
}

\section{A R T I C L E I N F O}

\section{Article history:}

Received 10 June 2014

Accepted 21 April 2015

Available online 30 April 2015

\section{Keywords:}

Source region of the Yangtze River

Hydrochemistry

Major ions

Water quality

Controlling factor

\begin{abstract}
A B S T R A C T
This study focuses on the chemical composition, and the factors controlling it, of the high mountain-rivers in the source region of the Yangtze River on the Tibetan Plateau. By comprehensive and systematic analysis, the chemical signatures, spatial variations of water quality, as well as the factors controlling them are studied. The value of the average total dissolved solids (TDS) is $778 \mathrm{mg} / \mathrm{l}$, ranging from 117 to $5496 \mathrm{mg} / \mathrm{l}$. In order of decreasing concentration, the main cations are $\mathrm{Na}^{+}, \mathrm{Ca}^{2+}, \mathrm{Mg}^{2+}$, and $\mathrm{K}^{+}$, while the main anions are $\mathrm{Cl}^{-}, \mathrm{HCO}_{3}^{-}, \mathrm{SO}_{4}^{2-}$, and $\mathrm{NO}_{3}^{-}$. $\mathrm{Na}^{+}$and $\mathrm{Cl}^{-}$are the dominant ions, accounting for $74.2 \%$ and $63.7 \%$ of the total cations and anions, respectively, followed by $\mathrm{Ca}^{2+}$ and $\mathrm{HCO}_{3}^{-}$, which account for $14.3 \%$ and $25 \%$, respectively. The Piper diagram shows the main water type to be $\mathrm{Cl}^{-} \cdot \mathrm{HCO}_{3}^{-}-\mathrm{Na}^{+} \cdot \mathrm{Ca}^{2+}$ type. From the Gibbs boomerang model, we conclude that the chemistry of the river water is controlled by lithogenic weathering processes. The Na-normalized ratio end-member diagram indicates that the weathering of silicates and carbonates is relatively significant, on the whole. There exists pronounced regional heterogeneity in the water chemistry and the factors affecting it. The northern rivers, including Chumaer He, Beilu He, and Ranchiqu, are mainly affected by evaporation and crystallization processes, while the southern rivers (Tuotuo He, Gaerqu, and Buqu) show effects from the weathering of carbonates and silicates.
\end{abstract}

(C) 2015 Elsevier B.V. All rights reserved.

\section{Introduction}

The source region of the Yangtze River (hereafter abbreviated as SRYR), which is well known as the "water tower of China" and which contributes nearly $25 \%$ of the total flow of the Yangtze River, is the main source of drinking water and is also crucial for agricultural use (Zhou et al., 2005; Hu et al., 2011). Due to the influence of natural processes and human activities, terrestrial surface water quality is experiencing different degrees of deterioration, and water environmental issues have become increasingly prominent all over the world (Chen et al., 2002; Li et al., 2008; Kumarasamy et al., 2014; Thomas et al., 2014). Thus, assessment of the hydrochemical status of surface water is urgently needed. Chemical studies on river water provide crucial information about environmental change, and contribute to determining the relationship between regional chemical weathering and hydrogeochemical reactions and their controlling factors (Han and Liu, 2000; Dalai et al., 2002; Wu et al., 2008). Additionally, they can be used to determine the origins of the main chemical signatures, the evolution of geochemical solutes, and relationship with the regional physical geography (Xia et al., 2008). Major-ion hydrochemistry studies of river water provide qualitative and quantitative research methods for

\footnotetext{
* Corresponding author. Tel.: +861064889436.

E-mail addresses: jianglg@outlook.com (L. Jiang), yaozj@igsnrr.ac.cn (Z. Yao).
}

evaluating the formation and evolution of water bodies as well as for conservation of water resources (Huang et al., 2011; Zhang et al., 2011).

The quality of river water is influenced by natural factors, such as weathering of rocks, rainfall, and human activities (Kumarasamy et al., 2014). Generally, the solutes of surface water are mainly derived from the weathering of continental rocks and erosion of soils in the drainage basin; these processes are the major components of the exogenic cycle of elements in the continent-river-ocean system (Sarin et al., 1989; Kumarasamy et al., 2014). A number of studies have shown that the composition of river water can be attributed mainly to silicate weathering and carbonate weathering (Han and Liu, 2004). In light of the significance of the water source and ecological environment in SRYR, it is important to understand the special pattern of hydrochemistry and dominant chemical weathering processes in this region.

Many previous studies have reported the major ion chemistry of the world's largest rivers, such as the Amazon River system (Gibbs, 1967; Stallard, 1980; Stallard and Edmond, 1981; Stallard and Edmond, 1983; Stallard and Edmond, 1987) and the Ganges-Brahmaputra (Sarin et al., 1989; Galy and France-Lanord, 1999). In China, most studies have focused on the Yangtze River (Chen et al., 2002; Li and Zhang, 2005), the Yellow River (Chen et al., 2005), the Han River (Li et al., 2008, 2009), and the Huai River (Zhang et al., 2011). However, there have been only a few studies on the hydrochemistry of the river water in SRYR. Although some researchers have studied the Yangtze River, 
their studies either did not include the headwaters or were based only on a few samples, and therefore, a comprehensive analysis of the origin and chemical characteristics of the water has not yet been performed. In addition, variation in the water quality of the river water remains unclear. Therefore, more studies are required to elucidate the spatial patterns of the river chemistry and the chemical weathering processes within SRYR.

In this study, we characterized the hydrochemistry of the main rivers in the SRYR on the Tibetan Plateau. Based on the chemical analysis of water samples from different rivers, hydrochemical signatures and the spatial differences of the water chemistry were investigated along with the factors controlling them.

\section{Study area}

The SRYR (Fig. 1), with an area of $12.24 \times 10^{4} \mathrm{~km}^{2}$, lies in the northeastern part of the Chuanxibei Plateau, the hinterland of the QinghaiTibet Plateau, which is called the roof of the world (Zhou et al., 2005; Yang et al., 2006). The SRYR is located between $90^{\circ} 33^{\prime}-95^{\circ} 20^{\prime} \mathrm{E}$ and $32^{\circ} 26^{\prime}-35^{\circ} 45^{\prime} \mathrm{N}$, stretching from the Tanggula Mt. in the south, to the Kunlun Mt. and the Hoh Xil Mt. in the north, and from the Ulan Ul and Jurhen Ul in the west, to the Bayan Har Mt. in the east (Fig. 1). The relief of SRYR is relatively flat, with a decreasing trend from west to east, and it has an average altitude of more than $4000 \mathrm{~m}$ a.s.l. (Deng, 1988). Owing to the high altitude, modern glaciers and permafrost are widespread in the SRYR (Pu et al., 1988). The river system in the SRYR has a fan-shaped distribution; the system includes the main tributaries, Qumaer He, Tuotuo He, Dam Qu, and Beilu He. Swamps and small lakes are scattered over the wide area (Su and Tang, 1987; Sun et al., 1988; Liang et al., 2011).

There are many different soil types in the SRYR, such as alpine desert soil, alpine meadow soil, alpine grassland soil, boggy soil, and mountain meadow soil. These soils are characterized by rough structure, a thin soil layer, greater gravel content, and poor maturity (Su and Tang, 1987; Deng, 1988; Wang et al., 2001). In addition, the soils are affected to varying degrees by salt accumulation due to arid climate. For instance, soils display apparent salt accumulation phenomena in the topsoil in the Tuotuo He basin; in particular, halite and gypsum/anhydrite occur widely in the area (Zhang et al., 1992; Pu and Wang, 1995). The alpine climate environment limits the occurrence and development of vegetation, and thus, the SRYR has a unique alpine arid ecology. The vegetation mainly consists of alpine meadow and alpine steppe species (Wang and Cheng, 2000). Broad meadow grassland covers most of the SRYR area, and it is dominated by dwarf wormwood meadow, Kobresia tibetica meadow, alpine shrub meadow, and alpine steppe meadow. The vegetation is mainly composed of hardy plants, such as Kobresia tibetica Maxim., Carex moorcroftii, Stipa aliena, Saussurea stoliczkai., Trollius chinensis Bunge, and Saussurea involucrata. Grass growth is slow and the vegetation is dwarf (Zhang et al., 1992; Wang et al., 2012).

The SRYR, which lies in the hinterland of the plateau and faces mountains to its north and south, is in a semi-closed state. With intensive solar radiation, the climate in the study area is cold and dry; it is mainly affected by warm moisture flow from the Indian Ocean-Bay of Bengal and upper westerlies, and belongs to the inland alpine semiarid and semi-humid climate transition zone (Su and Tang, 1987; Deng, 1988; Chen et al., 2008). The annual mean temperature is below $0{ }^{\circ} \mathrm{C}$ and the precipitation is approximately $372 \mathrm{~mm}$, mainly falling in the rainy season from May to October; the rainfall in this season accounts for more than $92 \%$ of the total annual precipitation (Wang and Cheng, 2000; Zhou et al., 2005; Liang et al., 2011).

Geologically, the SRYR drains between the Bayan Har fold belt and the Tanggula fold belt, and the strata exposed in the study area are mainly marine-terrigenous facies deposits from Permian to Quaternary in age (Qian et al., 2014). The strata are very thick and generally affected by regional low-grade metamorphism. In the north of

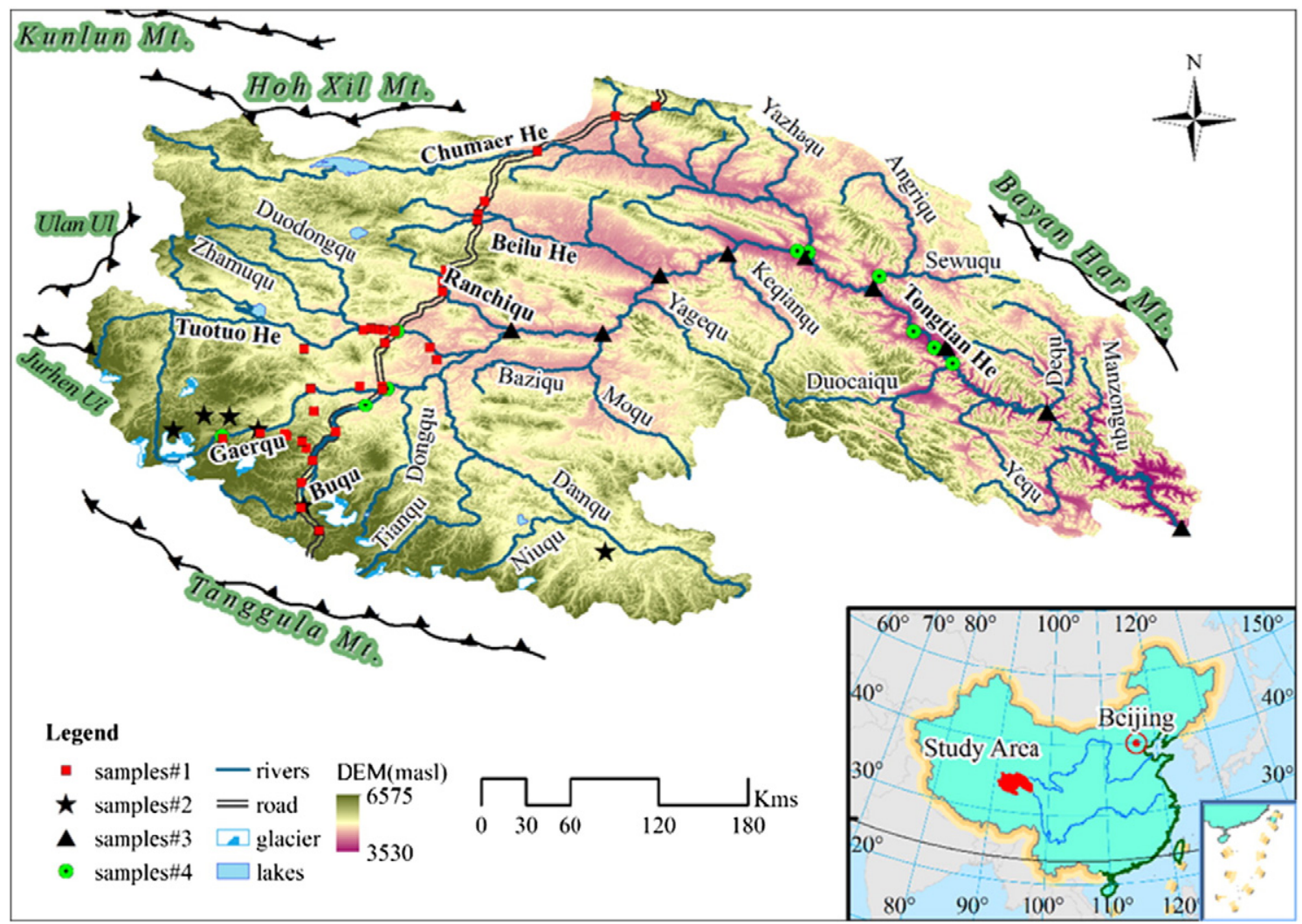

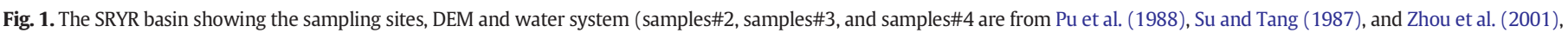
respectively). 
the Chumaer He-Tongtian He fault zone, the Permian and Triassic groups are well exposed, being composed of clastic rocks and carbonate sediments and clastic rocks, respectively, both of which are affected by regional low-grade metamorphism (Li et al., 2012). In the south, marine Jurassic strata are thick and widely exposed, mainly containing purple red clastic rocks, carbonate rocks intercalated with evaporates, and volcanic rocks (Wu et al., 2009). The other exposed strata are of Carboniferous, Triassic and Paleogene age. Among them, the Triassic strata are dominated by carbonate rocks, beneath which red clastic and carbonate rocks that are not affected by regional metamorphism are present ( $\mathrm{Li}$ et al., 2011). Sporadic small granitic intrusions occur in the source regions of Tuotuo He and Gaerqu along the south bank of Tongtian He. The granite rocks consist of gray and off-white, medium- and coarsegrained biotitic granite and granodiorite. Overall, the outcropping rocks are dominated by clastic rocks whose main constituents are sandstone and limestone (Fig. 2; Zhang et al., 1992; The China Geological Survey, 2004).

\section{Materials and methods}

A field survey was conducted across the Buqu, Gaerqu, Tuotuo He, Ranchiqu, Beilu He, and Chumaer He rivers along the No. 109 national road in July 2011. A total of 39 samples were collected at a depth of $10 \mathrm{~cm}$. Samples were stored in pre-cleaned polyethylene bottles free of air and filtered through $0.45 \mu \mathrm{m}$ Millipore nitrocellulose filters (MerckMillipore). Immediately after collection, a small portion of these samples was stored for anion analyses, while another portion was acidified with ultrapure $\mathrm{HCl}$ to a $\mathrm{pH}<2$.

The following parameters were measured in the field: $\mathrm{pH}$, water temperature, and conductivity by a Horiba U53 (HORIBA.Ltd, Kyoto, Japan) multi-meter, and carbonate alkalinity by titration using $\mathrm{HCl}$ and methylorange dye indicator. Upon returning to the laboratory at the Institute of Geographic Sciences and Natural Resources Research, CAS, the major cations $\left(\mathrm{K}^{+}, \mathrm{Na}^{+}, \mathrm{Ca}^{2+}, \mathrm{Mg}^{2+}\right)$ were analyzed using a Inductively Coupled Plasma Optical Emission Spectrometer (ICP-OES) (model ICPOES 5300DV (PerkinElmer Inc., USA)) with detection limit ranges of 0.1-1 ppb for $\mathrm{K}, \mathrm{Na}$ and $<0.1 \mathrm{ppb}$ for $\mathrm{Ca}$, $\mathrm{Mg}$. Additionally, anions $\left(\mathrm{Cl}^{-}\right.$, $\mathrm{NO}_{3}^{-}, \mathrm{SO}^{2-}{ }_{4}$ ) were determined by ion chromatography of model ICS-
2100 (Dionex Corporation, USA). The detection limits for $\mathrm{Cl}^{-}, \mathrm{SO}^{2-}{ }_{4}$ and $\mathrm{NO}_{3}^{-}$are $0.006,0.009$ and $0.05 \mathrm{ppm}$, respectively. The average analytical precision for all ions is better than $5 \%$.

In order to investigate the hydrochemical characteristics of different rivers of the SRYR, we also used some data from Pu et al. (1988), Su and Tang (1987), Zhao et al. (2003), and Zhou et al. (2001) regarding the Tongtian He, which is the main stream after the convergence of the Tuotuo He and Damqu. In total, we used 56 samples after elimination of some samples for data quality control (see data details in Appendix A).

A statistical program, SPSS v 20.0, was used to evaluate the relationships between various physiochemical parameters. The hydrochemical program, AquaChem v 4.0.278, was used to analyze the water quality and plot the water-type graph.

\section{Results and discussion}

\subsection{Major elements}

The statistical characteristics of all the samples are presented in Table 1 . The mean $\mathrm{pH}$ of the waters is slightly alkaline $(\mathrm{pH}=7.6)$, with values ranging from 6.0 to 8.7. The variation in $\mathrm{pH}$ is restricted to a limited extent with the coefficient of deviation being $8.5 \%$. The mean total dissolved solids (TDS) of the SRYR's rivers is $778 \mathrm{mg} / \mathrm{l}$, which is more than 7 times on average than the world average of $100 \mathrm{mg} / \mathrm{l}$ (Roy et al., 1999) and nearly 3 times that of the world's large rivers (283 mg/l) (Han and Liu, 2004). The values range from 117 to $5496 \mathrm{mg} /$ 1 due to the different formations outcropping; the former value mainly occurs in the southern rivers (Gaerqu, Buqu), reflecting the weathering of clastic rocks, whereas the latter mainly occurs in the northern rivers (Beilu He, Chumaer He, Ranchiqu), probably due to dissolution of evaporites. Globally, the order of the mean concentration of major ions is $\mathrm{Na}>\mathrm{Ca}>\mathrm{Mg}>\mathrm{K}$ for cations, and $\mathrm{Cl}>\mathrm{Alk}>\mathrm{SO}_{4}>\mathrm{NO}_{3}$ for anions (Table 1), with $\mathrm{Na}$ and $\mathrm{Cl}$ accounting for $74.2 \%$ and $63.7 \%$ of the total concentration of cations and anions, respectively. However, all ions but Alk show a coefficient of variation (C.V.) higher than 50\%. In particular, the C.V. $>100 \%$ of chloride, sodium, and sulfate reflects the high solubility of halites and gypsum/anhydrite, further supporting the interaction of the waters with evaporites.

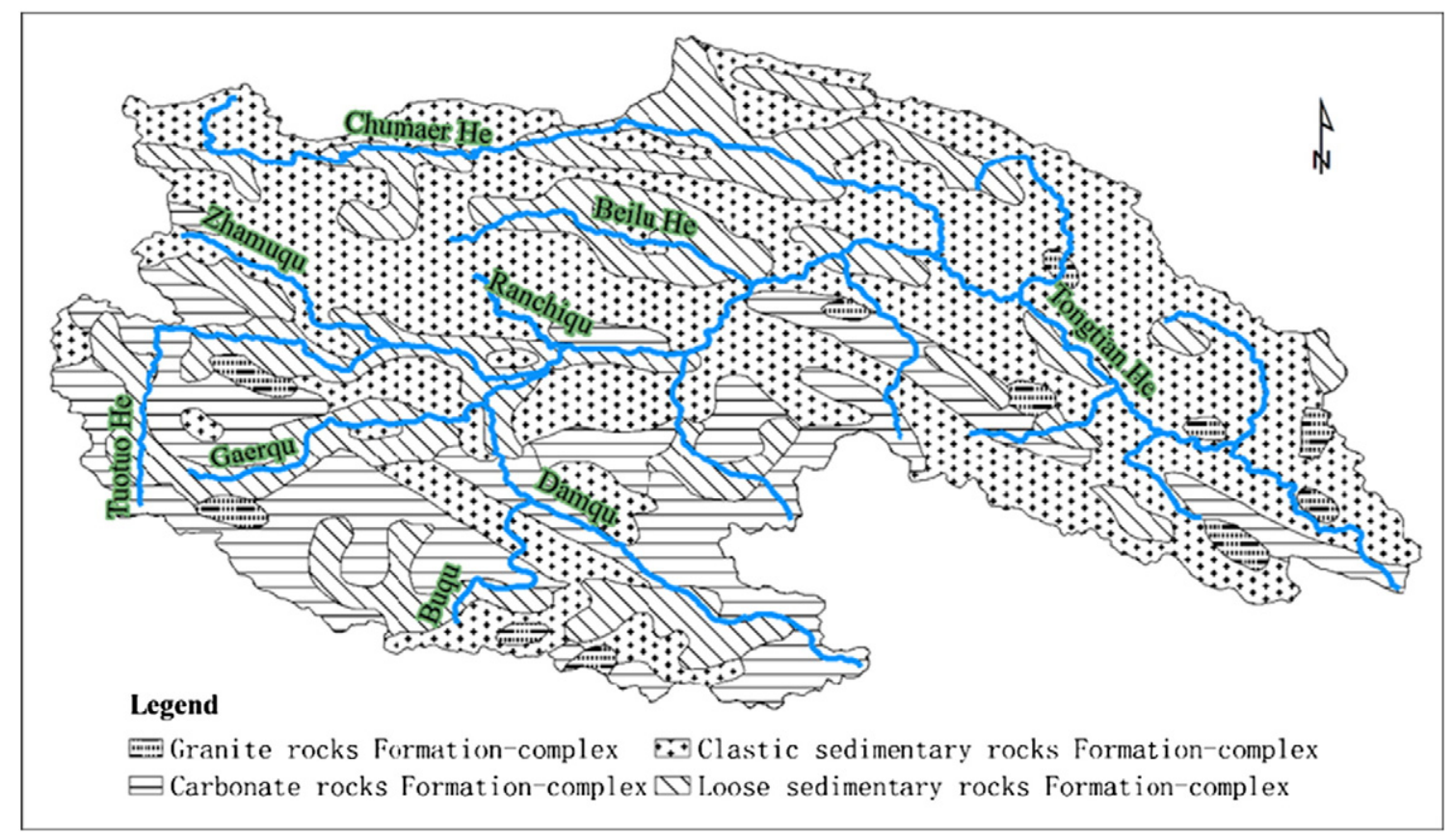

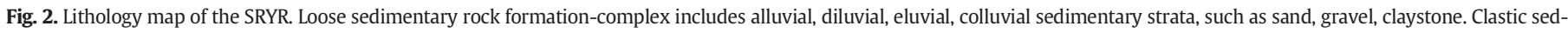

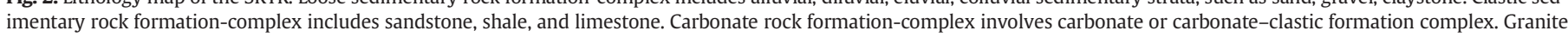
rock formation-complex includes granite, granite porphyry, feldspars, and granodiotire. 
Table 1

Descriptive statistics of hydrochemistry of all available water samples.

\begin{tabular}{lllcccrc}
\hline Parameter & Sample num & Unit & Min & Max & Average & S.D. & C.V. $\left.{ }^{\text {b }} \%\right)$ \\
\hline $\mathrm{Ca}$ & 56 & $\mathrm{mg} / \mathrm{l}$ & 7.0 & 182.0 & 53.4 & 39.1 & 73.2 \\
$\mathrm{Mg}$ & 56 & $\mathrm{mg} / \mathrm{l}$ & 2.2 & 101.8 & 22.9 & 18.5 & 80.5 \\
$\mathrm{Na}$ & 56 & $\mathrm{mg} / \mathrm{l}$ & 2.2 & 1854 & 157.7 & 298.4 & 189.3 \\
$\mathrm{~K}$ & 56 & $\mathrm{mg} / \mathrm{l}$ & 0.7 & 26.1 & 5.5 & 5.6 & 100.8 \\
$\mathrm{Cl}$ & 56 & $\mathrm{mg} / \mathrm{l}$ & 1.5 & 2910 & 233.7 & 470.4 & 201.3 \\
$\mathrm{Alk}^{\mathrm{c}}$ & 56 & $\mathrm{mg} / \mathrm{l}$ & 15.9 & 366.6 & 188.5 & 82.2 & 43.6 \\
$\mathrm{SO}_{4}$ & 56 & $\mathrm{mg} / \mathrm{l}$ & 8.7 & 830.7 & 114.9 & 150.5 & 131.0 \\
$\mathrm{NO}_{3}$ & 45 & $\mathrm{mg} / \mathrm{l}$ & 0.0 & 5.0 & 1.3 & 1.0 & 83.6 \\
$\mathrm{pH}$ & 49 & & 6.0 & 8.7 & 7.6 & 0.6 & 8.5 \\
$\mathrm{TDS}$ & 56 & $\mathrm{mg} / \mathrm{l}$ & 117 & 5496 & 778 & 915.7 & 117.8 \\
\hline
\end{tabular}

a S.D.: standard deviation.

b C.V.: coefficient of variation.

c Alk: (alkalinity) $=\mathrm{HCO}_{3}^{-}+\mathrm{CO}_{3}^{2-}$.

Correlation analysis for the major ions demonstrates that the TDS has a positive relationship with the rest of the variables, while $\mathrm{NO}_{3}$ and Alk have low coefficients, which may be explained by their high variation. Chloride, $\mathrm{Na}, \mathrm{Ca}$, and $\mathrm{Mg}$ show positive correlations, and their significant contribution to the overall chemical composition is demonstrated by their significant correlation with the TDS $(\mathrm{P}<0.01)$. Of all the correlation ion pairs, the positive correlation coefficients for " $\mathrm{Cl}-\mathrm{Na}, \mathrm{K}$ " ( $\mathrm{R}>0.8$, $\mathrm{P}<0.01)$ and " $\mathrm{SO}_{4}-\mathrm{Ca}, \mathrm{Mg}$ " $(\mathrm{R}>0.6, \mathrm{P}<0.01)$ are highest, indicating that $\mathrm{Na}-\mathrm{K}$ and $\mathrm{Ca}-\mathrm{Mg}$ may have good homology and that they have a certain similarity of origins and existence modes. The correlation of $\mathrm{SO}_{4}$ with $\mathrm{Mg}$ and Ca suggests that the sulfate is mainly associated with magnesium sulfate (e.g., epsom salt) or gypsum/anhydrite (Noh et al., 2009). Nevertheless, although the coefficient is low, $\mathrm{SO}_{4}$ is negatively correlated with Alk (Table 2).

\subsection{Spatial variation}

To explore the regional differentiation and differences between rivers, the samples were classified into categories according to the river. We carried out statistical analysis of different categories (Table 3). The northern rivers refer to those to the north of Tongtian He, including Beilu He, Ranchiqu, and Chumaer He. The main characteristics of these rivers are: TDS greater than $1000 \mathrm{mg} / \mathrm{l}$ and water type being $\mathrm{Na}-\mathrm{Cl}$ because of lower precipitation and higher evaporation (Yang, 2005). High salinity is due to concentration through evaporation, which accelerates the accumulation of salt in water. The $\mathrm{Cl} / \mathrm{Na}$ molar ratios of Chumaer $\mathrm{He}$ and Beilu He are slightly greater than 1, almost the same as halite, reflecting the typical dissolution of evaporites (e.g., salt rock and gypsum strata) (Zhao et al., 2003). The southern rivers, Gaerqu, Tuotuo $\mathrm{He}$, and Buqu, have less TDS than the northern rivers (order of magnitude of a hundred). The salinity of these rivers is relatively lower because glacier melt water is an important supply source for these rivers. The samples from these rivers are mainly composed of bicarbonate due to the widespread distribution of carbonate rocks there (Fig. 2).
Table 3

Statistical characteristics of different rivers (mean value).

\begin{tabular}{|c|c|c|c|c|c|c|c|c|c|c|}
\hline Rivers & $\mathrm{PH}$ & K & $\mathrm{Na}$ & $\mathrm{Ca}$ & $\mathrm{Mg}$ & $\mathrm{Cl}$ & $\mathrm{NO}_{3}$ & $\mathrm{SO}_{4}$ & Alk & TDS \\
\hline Gaerqu & 7.1 & 2.8 & 19.2 & 42.4 & 12.4 & 15.5 & 0.9 & 62.7 & 132.2 & 288 \\
\hline Tuotuo He & 7.8 & 6.4 & 118.7 & 30.7 & 25.4 & 133.4 & 2.1 & 78.8 & 273.1 & 668 \\
\hline Buqu & 7.8 & 3.3 & 55.6 & 39.8 & 14.7 & 75.6 & 0.6 & 56.0 & 171.6 & 417 \\
\hline $\begin{array}{c}\text { Chumaer } \\
\text { He }\end{array}$ & 7.8 & 5.9 & 271.9 & 47.6 & 38.9 & 433.0 & 1.4 & 141.1 & 173.3 & 1113 \\
\hline Beilu He & 7.8 & 16.7 & 1089 & 123.3 & 58.1 & 1696 & 2.8 & 486.3 & 172.8 & 3645 \\
\hline Ranchiqu & 7.9 & 7.1 & 266.3 & 65.6 & 36.7 & 345.3 & 0.7 & 310.6 & 231.9 & 1264 \\
\hline $\begin{array}{l}\text { Tongtian } \\
\mathrm{He}\end{array}$ & 7.6 & 5.9 & 105.8 & 70.8 & 20.0 & 187.4 & 1.3 & 82.9 & 184.0 & 657 \\
\hline
\end{tabular}

Their $\mathrm{Cl} / \mathrm{Na}$ molar ratios are no more than 0.88 , except in some samples from Tuotuo He.

Piper ternary diagrams (Fig. 3) provide a way to visualize the compositions and water types of rivers, and therefore, can show the relative importance of different weathering regimes (Huh et al., 1998). The diagrams show the wide diversity of samples from different rivers. On the cation diagram, samples from Buqu, Gaerqu lie in the lower-left corner, where the Ca values are high (more than 50\%), revealing that the dominant cation in these samples is calcium. On the contrary, the others mostly fall on the lower-right corner and on the middle line of $\mathrm{Ca}$ : $\mathrm{Mg}=1: 1$, where the dominant ion is sodium showing the characteristics of evaporites. On the anion diagram, the samples from Buqu, Gaerqu and Tuotuo He fall on the lower-left corner, the alkalinity apex, showing carbonate weathering features. However, samples from Tongtian He, Beilu He fall on the lower-right corner revealing chloride-dominated features. Nevertheless, the values of samples from Chumaer He are relatively scattered, but still show chloride-dominated features overall. Samples from Ranchiqu have very low alkalinity and their dominant ions, chloride and sulfate, are nearly equivalent, which makes them exceptional. According to the Piper diagram (Fig. 3), the water types of Gaerqu, Tuotuo He, Buqu, Chumaer He, Beilu He, Ranchiqu, and Tongtian $\mathrm{He}$ are $\mathrm{HCO}_{3}-\mathrm{Ca}, \mathrm{HCO}_{3}-\mathrm{Na}, \mathrm{HCO}_{3}-\mathrm{Ca} \cdot \mathrm{Ma}, \mathrm{Cl}-\mathrm{Na}, \mathrm{Cl}-\mathrm{Na}$, $\mathrm{Cl} \cdot \mathrm{SO}_{4}-\mathrm{Na}$, and $\mathrm{Cl} \cdot \mathrm{HCO}_{3}-\mathrm{Na} \cdot \mathrm{Ca}$, respectively. Overall the distributions are indicative of weathering of platform carbonates and evaporites.

On the whole, regional heterogeneity is obvious. Northern rivers have evaporite-related characteristics, i.e. $\mathrm{Na}-\mathrm{Cl}$ water type. They drain sedimentary rocks, and ions probably come from halite, anhydrite, and gypsum because of the relatively higher $\mathrm{SO}_{4}$ content. However, the southern rivers show carbonate features; most of the samples from here have a $\mathrm{Na} \cdot \mathrm{Ca}-\mathrm{HCO}_{3}$ water type due to the carbonate rock formations/ complexes (Fig. 2).

\subsection{Mechanisms controlling the major-ion chemistry}

Gibbs (1970) defined the mechanisms controlling world surface water chemistry as three end-members: atmospheric precipitation, rock dominance, and the evaporation-crystallization process on the

Table 2

Pearson correlations of major ions and TDS in rivers.

\begin{tabular}{|c|c|c|c|c|c|c|c|c|c|c|}
\hline & K & $\mathrm{Na}$ & $\mathrm{Ca}$ & $\mathrm{Mg}$ & $\mathrm{Cl}$ & $\mathrm{SO}_{4}$ & $\mathrm{NO}_{3}$ & Alk & TDS & $\mathrm{pH}$ \\
\hline K & 1 & & & & & & & & & \\
\hline $\mathrm{Na}$ & $0.83^{\text {** }}$ & 1 & & & & & & & & \\
\hline $\mathrm{Ca}$ & $0.55^{* *}$ & $0.57^{* *}$ & 1 & & & & & & & \\
\hline $\mathrm{Mg}$ & $0.58^{* *}$ & $0.53^{* *}$ & $0.41^{* *}$ & 1 & & & & & & \\
\hline $\mathrm{Cl}$ & $0.82^{* *}$ & $1.00^{* *}$ & $0.62^{* *}$ & $0.51^{* *}$ & 1 & & & & & \\
\hline $\mathrm{SO}_{4}$ & $0.56^{\text {** }}$ & $0.63^{\text {** }}$ & $0.69^{* *}$ & $0.73^{* *}$ & $0.61^{* *}$ & 1 & & & & \\
\hline $\mathrm{NO}_{3}$ & 0.12 & 0.03 & 0.02 & $0.34^{*}$ & 0.02 & 0.22 & 1 & & & \\
\hline Alk & 0.20 & 0.04 & -0.11 & $0.36^{* *}$ & -0.01 & -0.04 & 0.15 & 1 & & \\
\hline TDS & $0.84^{* *}$ & $0.98^{* *}$ & $0.66^{* *}$ & $0.63^{* *}$ & $0.98^{* *}$ & $0.73^{* *}$ & 0.08 & 0.1 & 1 & \\
\hline $\mathrm{pH}$ & -0.08 & 0.03 & $-0.55^{* *}$ & -0.01 & -0.03 & -0.04 & 0.18 & -0.06 & -0.05 & 1 \\
\hline
\end{tabular}

Bold values represent correlation with significance.

** Correlation is significant at the 0.01 level.

* Correlation is significant at the 0.05 level. 


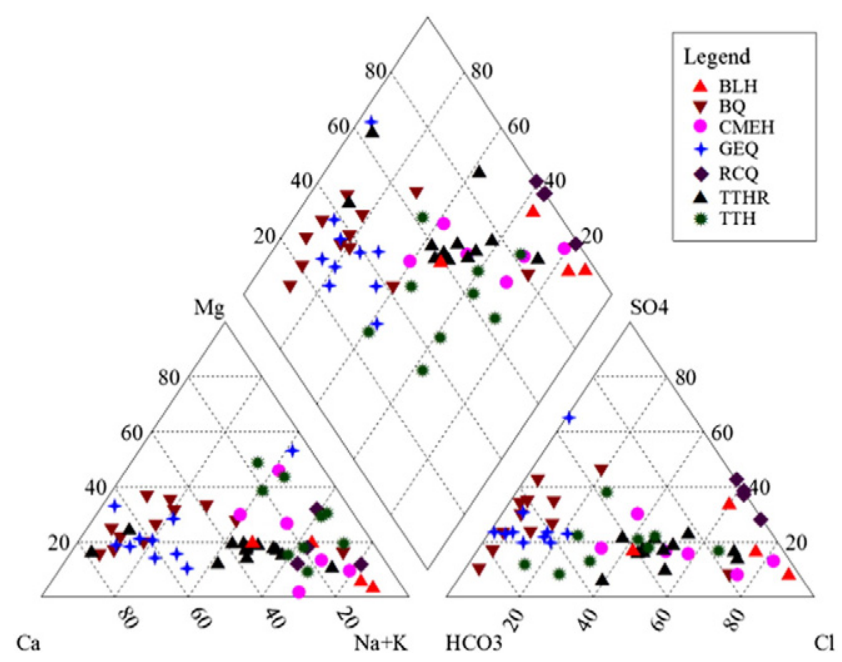

Fig. 3. Piper diagram for the water samples in different rivers. In the key: BLH (Beilu He), BQ (Buqu), CMEH (Chumaer He), GEQ (Gaerqu), RCQ (Ranchiqu), TTHR (Tongtian He) and TTH (Tuotuo He).

basis of analyzing numerous rain, river, lake, and ocean samples. To distinguish the contribution of the three end-members, TDS versus $\mathrm{Na}$ / $(\mathrm{Na}+\mathrm{Ca})$ or TDS versus $\mathrm{Cl} /\left(\mathrm{Cl}+\mathrm{HCO}_{3}\right)$ are used (Fig. 4; Gibbs, 1970). In general, samples with low salinity (TDS approximates $10 \mathrm{mg} / \mathrm{l})$ and high ratio of $\mathrm{Na} /(\mathrm{Na}+\mathrm{Ca})$ or $\mathrm{Cl} /\left(\mathrm{Cl}+\mathrm{HCO}_{3}\right)$ (approaching to 1 ) fall on the lower-right corner, reflecting the influence of precipitation. Samples with medium salinity (about 70 to $300 \mathrm{mg} / \mathrm{l}$ ) and low ratio of $\mathrm{Na} /(\mathrm{Na}+\mathrm{Ca})$ or $\mathrm{Cl} /\left(\mathrm{Cl}+\mathrm{HCO}_{3}\right)$ (less than 0.5$)$ locate on the left side of the central area, indicating that the dominant end-member is rock weathering. The third case, samples with high salinity and high ratio of $\mathrm{Na} /(\mathrm{Na}+\mathrm{Ca})$ or $\mathrm{Cl} /\left(\mathrm{Cl}+\mathrm{HCO}_{3}\right)$ (approaching to 1 ) fall on the upper-right corner, indicating that the dominant factor is evaporation-crystallization (Stallard and Edmond, 1983; Chen, 1987).

The Gibbs schematic diagram is shown in Fig. 4. The diagram reveals that the river waters of Gaerqu and Buqu are characterized by low ratios of $\mathrm{Na} /(\mathrm{Na}+\mathrm{Ca})$ and $\mathrm{Cl} /\left(\mathrm{Cl}+\mathrm{HCO}_{3}\right)$ and moderate concentrations of
TDS, typical of rock dominance rivers. Beilu He, Chumaer He, and Ranchiqu are characterized by high ratios of $\mathrm{Na} /(\mathrm{Na}+\mathrm{Ca})$ and $\mathrm{Cl} /$ $\left(\mathrm{Cl}+\mathrm{HCO}_{3}\right)$ and high concentrations of TDS, showing that the controlling factor is evaporation-crystallization processes. However, Tuotuo He and Tongtian $\mathrm{He}$ are in an intermediate state, having moderate values of TDS and ratios of $\mathrm{Na} /(\mathrm{Na}+\mathrm{Ca})$ and $\mathrm{Cl} /\left(\mathrm{Cl}+\mathrm{HCO}_{3}\right)$; they are controlled by rock weathering and evaporation-crystallization processes.

These results and conclusions are consistent with the ternary diagram (Fig. 3). The northern rivers are mainly affected by evaporationcrystallization, which is not surprising. From the meteorological point of view, strong radiation, strong evaporation, and low precipitation result in evaporite concentration. Taking the lithology into consideration, northern rivers are mainly controlled by lacustrine sediment, which provide a large amount of halite $(\mathrm{NaCl})$ into dissolved ions (Zhang, 2009). Additionally, groundwater recharge brings leached salts to the surface, resulting in salt-accumulation. The southern rivers (except Tuotuo $\mathrm{He}$ ) are mainly controlled by rock weathering. Tuotuo He and Tongtian He are controlled by two end members, rock dominance and evaporation-crystallization. Whatever the case may be, none of the rivers are affected by precipitation.

\subsection{Chemical weathering}

Weathering of different rocks yields different combinations of ions to a solution. For instance, $\mathrm{Ca}$ and $\mathrm{Mg}$ mainly originate from the weathering of carbonates, silicates, and evaporites, $\mathrm{Na}$ and $\mathrm{K}$ from the weathering of evaporites and silicates, $\mathrm{HCO}_{3}$ from carbonates and silicates, and $\mathrm{SO}_{4}$ and $\mathrm{Cl}$ from evaporites (Chen et al., 2002). Combinations of the three representative lithologies, i.e., evaporites, carbonates, and silicates, can be displayed on plots of Na-normalized molar ratios (Fig. 5). The mixing diagram is usually used to show the origins of the ions produced by chemical weathering in a basin with complex lithology (Gaillardet et al., 1999; Gao and Tao, 2010).

The samples from Beilu He, Chumaer He, Tuotuo He, and Ranchiqu plot between the silicate and the evaporite end-members, whereas the samples from Buqu and Gaerqu plot between the carbonate and the silicate end-members. Halite and gypsum/anhydrite are the two most common evaporites that can affect river water chemistry (Moon et al., 2007). Nevertheless, samples from Tongtian He distribute widely

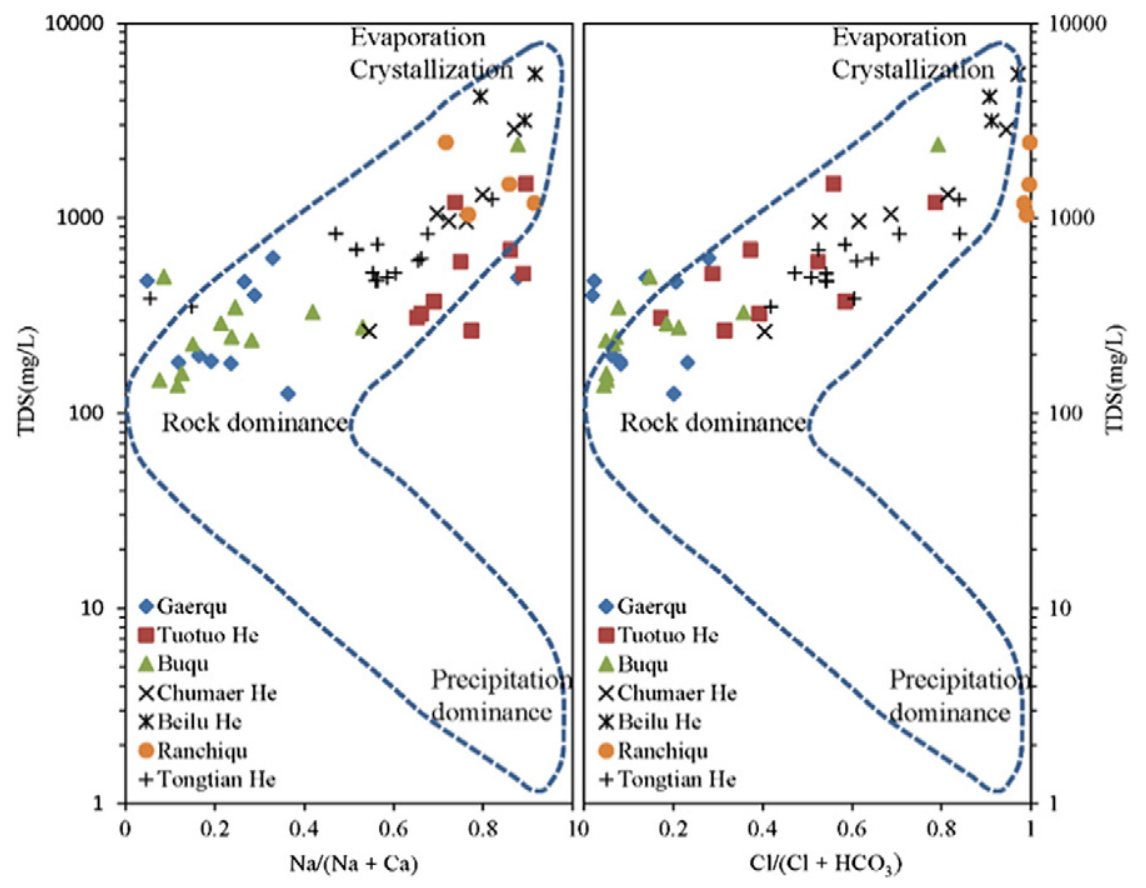

Fig. 4. Plot of the major ions within the Gibbs boomerang envelope for rivers. 

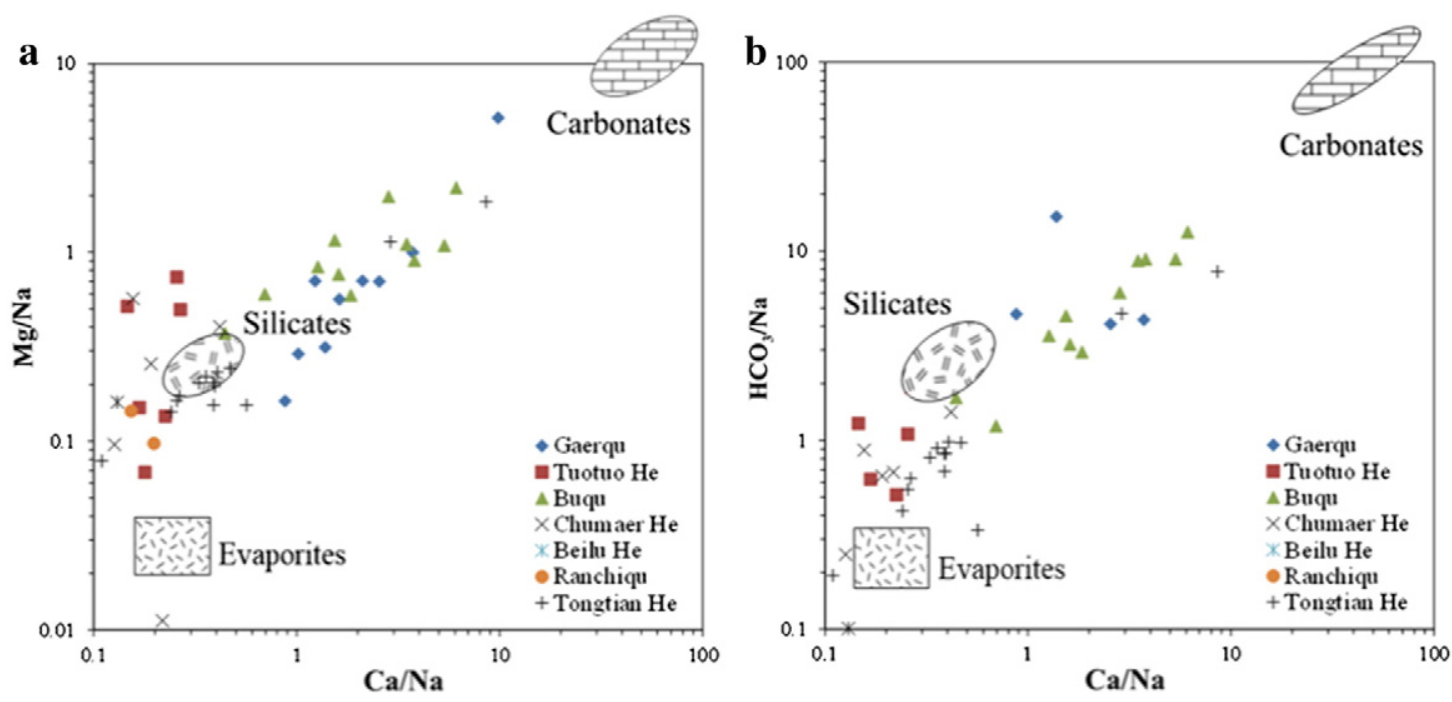

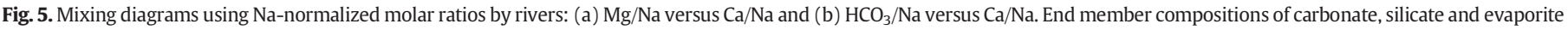
are from Gaillardet et al. (1999).

in the diagram. This is possibly due to the recharge with different chemical compositions of tributaries in the upper reaches.

Generally, K and Na are derived from evaporite dissolution and silicate weathering in rock weathering dominated rivers. The strong correlations between $\mathrm{Cl}, \mathrm{SO}_{4}, \mathrm{Na}$, and $\mathrm{K}$ suggest that they originated from the weathering of evaporite, especially in Ranchiqu and Beilu He.

In summary, the samples from the northern and southern rivers exhibit distinct differences in the type of chemical weathering affecting them. The northern rivers are mainly dominated by evaporite dissolution, while the southern rivers and Tongtian He are dominated by silicate and carbonate weathering.

\section{Conclusions}

The hydrochemistry of surface water in the SRYR is slightly alkaline with high TDS, the average value of which is $778 \mathrm{mg} / \mathrm{l}$, which is nearly three times that of the world's large rivers $(283 \mathrm{mg} / \mathrm{l})$. Na, $\mathrm{Ca}, \mathrm{Cl}$, and $\mathrm{HCO}_{3}$ are the principal chemical components in the surface water of the SRYR. The water types of Gaerqu, Tuotuo He, Buqu, Chumaer He, Beilu $\mathrm{He}$, Ranchiqu, and Tongtian $\mathrm{He}$ are $\mathrm{HCO}_{3}-\mathrm{Ca}, \mathrm{HCO}_{3}-\mathrm{Na}, \mathrm{HCO}_{3}-\mathrm{Ca} \cdot \mathrm{Ma}$,
$\mathrm{Cl}-\mathrm{Na}, \mathrm{Cl}-\mathrm{Na}, \mathrm{Cl} \cdot \mathrm{SO}_{4}-\mathrm{Na}$, and $\mathrm{Cl} \cdot \mathrm{HCO}_{3}-\mathrm{Na} \cdot \mathrm{Ca}$, respectively. As a whole, the waters exhibit water type of chloride, bicarbonate-sodium, and calcium.

In addition, there is large spatial variability in the hydrochemistry of the water in the different rivers of the SRYR due to the complex geologic makeup of the drainage basins. The northern rivers, including Chumaer $\mathrm{He}$, Beilu He, and Ranchiqu, are mainly affected by evaporite dissolution, while the southern rivers (Tuotuo He, Gaerqu, and Buqu) show weathering from carbonates and silicates, and Tongtian He are dominated by silicates and carbonates weathering. With respect to the water type, Chumaer He and Beilu He belong to a typical $\mathrm{Na}-\mathrm{Cl}$ water type.

\section{Acknowledgments}

The research is jointly supported by the Major Program of the National Natural Science Foundation of China (Grant No. 41190080), the National Basic Research Program of China (Grant No. 2010CB951700), and the National Natural Science Foundation of China (Grant No. 41201035). We would like to thank Guoan Yu, Xiaofang Liu, Yuanxu Ma, Siyang Yu and Zhanlong Sun for their help during the samples collection, and Prof. Xianfang Song for the suggestions.

\section{Appendix A}

Table A1. Major ion composition of rivers in the source region of Yangtze river.

\begin{tabular}{|c|c|c|c|c|c|c|c|c|c|c|c|c|c|c|c|}
\hline Data source & NO. ${ }^{a}$ & $\begin{array}{l}\text { Sample } \\
\text { ID }^{\text {b }}\end{array}$ & Location $^{\mathrm{c}}$ & $\begin{array}{l}\text { Elevation } \\
\mathrm{m}\end{array}$ & $\mathrm{pH}$ & $\begin{array}{l}\mathrm{K} \\
\mathrm{mg} / 1\end{array}$ & $\begin{array}{l}\mathrm{Na} \\
\mathrm{mg} / \mathrm{l}\end{array}$ & $\begin{array}{l}\mathrm{Ca} \\
\mathrm{mg} / 1\end{array}$ & $\begin{array}{l}\mathrm{Mg} \\
\mathrm{mg} / \mathrm{l}\end{array}$ & $\begin{array}{l}\mathrm{Cl} \\
\mathrm{mg} / \mathrm{l}\end{array}$ & $\begin{array}{l}\mathrm{NO}_{3} \\
\mathrm{mg} / \mathrm{l}\end{array}$ & $\begin{array}{l}\mathrm{SO}_{4} \\
\mathrm{mg} / 1\end{array}$ & $\begin{array}{l}\text { Alk } \\
\mathrm{mg} / \mathrm{l}\end{array}$ & $\begin{array}{l}\text { TDS } \\
\mathrm{mg} / \mathrm{l}\end{array}$ & $\begin{array}{l}\mathrm{NICB}^{\mathrm{d}} \\
\%\end{array}$ \\
\hline \multicolumn{16}{|l|}{ Gaerqu } \\
\hline Pu et al., 1988 & 1 & 15 & Jianggengqu & 5900 & 7.76 & 1.94 & 8.25 & 36.0 & 6.01 & 4.43 & - & 27.6 & 112.8 & 198 & 7 \\
\hline Pu et al., 1988 & 2 & 18 & Qiesumeiqu & 5160 & 7.26 & 2.00 & 13.0 & 19.2 & 2.21 & 9.22 & - & 16.9 & 63.0 & 126 & 8.2 \\
\hline Zhou et al., 2001 & 3 & Q9 & Jianggenqu & 4998 & 6.20 & 2.23 & 7.39 & 47.8 & 7.67 & 22.2 & - & 31.2 & 125.7 & 244 & 1.8 \\
\hline Zhou et al., 2001 & 4 & Q8 & Gaerqu & 4570 & 6.00 & 4.96 & 43.8 & 105.3 & 14.3 & 47.7 & - & 94.6 & 314.2 & 625 & -0.1 \\
\hline Zhao et al., 2003 & 5 & - & Gaerqu & - & - & 2.73 & 23.9 & 42.4 & 7.20 & 26.3 & 1.86 & 37.4 & 116.5 & 258 & 9.7 \\
\hline This study & 6 & 20 & Source of Gaerqu & 4650 & 6.90 & 8.60 & 57.2 & 6.90 & 41.7 & 27.6 & 0.80 & 64.8 & 293.0 & 501 & 4.0 \\
\hline This study & 7 & 29 & Trib.1 of Gaerqu & 4929 & 7.09 & 1.35 & 12.3 & 26.3 & 9.01 & 1.50 & 0.56 & 32.4 & 33.6 & 117 & 2.2 \\
\hline This study & 8 & 30 & Trib.2 of Gaerqu & 4841 & 7.87 & 1.66 & 10.6 & 38.8 & 7.79 & 6.67 & 0.35 & 48.7 & 116.0 & 231 & 8.5 \\
\hline This study & 9 & 31 & Up. reach of Gaerqu & 5007 & 7.95 & 1.73 & 11.4 & 32.2 & 6.70 & 6.87 & 0.45 & 34.3 & 131.1 & 225 & 0.2 \\
\hline This study & 10 & 32 & Trib.3 of Gaerqu & 4870 & 6.95 & 0.71 & 3.95 & 67.6 & 21.3 & 2.24 & 1.23 & 238.8 & 15.9 & 352 & 3.1 \\
\hline
\end{tabular}


Appendix A (continued)

\begin{tabular}{|c|c|c|c|c|c|c|c|c|c|c|c|c|c|c|c|}
\hline Data source & NO. ${ }^{a}$ & $\begin{array}{l}\text { Sample } \\
\text { ID }^{\mathrm{b}}\end{array}$ & Location $^{\mathrm{c}}$ & $\begin{array}{l}\text { Elevation } \\
\mathrm{m}\end{array}$ & $\mathrm{pH}$ & $\begin{array}{l}\mathrm{K} \\
\mathrm{mg} / \mathrm{l}\end{array}$ & $\begin{array}{l}\mathrm{Na} \\
\mathrm{mg} / \mathrm{l}\end{array}$ & $\begin{array}{l}\mathrm{Ca} \\
\mathrm{mg} / \mathrm{l}\end{array}$ & $\begin{array}{l}\mathrm{Mg} \\
\mathrm{mg} / \mathrm{l}\end{array}$ & $\begin{array}{l}\mathrm{Cl} \\
\mathrm{mg} / \mathrm{l}\end{array}$ & $\begin{array}{l}\mathrm{NO}_{3} \\
\mathrm{mg} / \mathrm{l}\end{array}$ & $\begin{array}{l}\mathrm{SO}_{4} \\
\mathrm{mg} / \mathrm{l}\end{array}$ & $\begin{array}{l}\text { Alk } \\
\mathrm{mg} / \mathrm{l}\end{array}$ & $\begin{array}{l}\text { TDS } \\
\mathrm{mg} / \mathrm{l}\end{array}$ & $\begin{array}{l}\mathrm{NICB}^{\mathrm{d}} \\
\%\end{array}$ \\
\hline \multicolumn{16}{|l|}{ Tuotuo He } \\
\hline Zhou et al., 2001 & 11 & Q7 & Bridge of Tuotuo He & 4534 & 6.00 & 16.6 & 316.3 & 98.1 & 22.6 & 471 & - & 161.9 & 213.5 & 1300 & 3.4 \\
\hline This study & 12 & 33 & Lo. reach of Tuotuo He & 4511 & 8.15 & 9.78 & 126.2 & 49.4 & 17.9 & 140.9 & 3.31 & 90.3 & 171.9 & 610 & 2.7 \\
\hline This study & 13 & $\mathrm{~T} 1$ & $19 \mathrm{~km}$ from the source & 4590 & 7.84 & 6.28 & 83.6 & 24.4 & 13.2 & 88.3 & 2.76 & 59.4 & 237.9 & 516 & 1.3 \\
\hline This study & 14 & $\mathrm{~T} 2$ & RB Trib.1 of Tuotuo He & 4567 & 7.60 & 5.74 & 181.3 & 18.4 & 25.9 & 195.6 & 1.97 & 101.4 & 366.6 & 897 & -8.2 \\
\hline This study & 15 & T3 & $12 \mathrm{~km}$ from the source & 4585 & 8.65 & 5.11 & 73.2 & 7.90 & 19.5 & 53.1 & 1.53 & 21.7 & 266.3 & 448 & -6.3 \\
\hline This study & 16 & $\mathrm{~T} 4$ & RB Trib.2 of Tuotuo He & 4578 & 8.11 & 2.89 & 43.6 & 20.2 & 22.6 & 26.7 & 0.93 & 27.6 & 320.1 & 465 & -2.0 \\
\hline This study & 17 & T5 & RB Trib.3 of Tuotuo He & 4565 & - & 4.33 & 129.6 & 18.2 & 33.1 & 113.7 & 1.64 & 60.3 & 329.1 & 690 & -5.0 \\
\hline This study & 18 & T6 & RB Trib.4 of Tuotuo He & 4563 & 8.14 & 3.11 & 53.5 & 23.8 & 41.0 & 57.6 & 2.17 & 121.4 & 253.1 & 556 & 4.5 \\
\hline This study & 19 & $\mathrm{~T} 7$ & RB Trib.5 of Tuotuo He & 4554 & 8.02 & 3.51 & 61.2 & 15.6 & 32.9 & 53.2 & 2.09 & 65.0 & 299.3 & 533 & 1.9 \\
\hline \multicolumn{16}{|l|}{ Buqu } \\
\hline Pu et al., 1988 & 20 & 19 & Up. reach of Buqu & 4880 & 7.68 & 1.33 & 3.90 & 25.7 & 3.68 & 2.58 & - & 8.7 & 93.9 & 140 & 0.0 \\
\hline Zhao et al., 2003 & 21 & - & Buqu & - & - & 1.95 & 16.3 & 52.4 & 10.1 & 16.7 & 1.86 & 64.3 & 126.3 & 290 & 7.3 \\
\hline Zhao et al., 2003 & 22 & - & Up. reach of Buqu & - & - & 0.78 & 4.37 & 26.4 & 5.04 & 3.20 & 0.00 & 17.3 & 103.1 & 160 & -9.8 \\
\hline Zhou et al., 2001 & 23 & Q10 & Yanshiping & 4611 & 7.00 & 2.41 & 11.2 & 103.6 & 12.6 & 27.0 & 0.00 & 75.8 & 269.1 & 502 & 0.5 \\
\hline This study & 24 & 10 & G109-3195 & 4577 & 7.64 & 23.6 & 519.1 & 62.9 & 60.9 & 774.4 & 1.30 & 114.2 & 348.2 & 1905 & 4.7 \\
\hline This study & 25 & 12 & Yanshiping & 4701 & 7.77 & 1.12 & 12.8 & 35.8 & 10.2 & 4.89 & 0.50 & 48.9 & 140.4 & 255 & 8.6 \\
\hline This study & 26 & 13 & Trib. of Buqu & 4784 & 7.85 & 1.25 & 42.5 & 51.3 & 26.6 & 43.3 & 0.51 & 141.0 & 134.3 & 441 & 4.4 \\
\hline This study & 27 & 14 & G109-3289 & 4849 & 7.84 & 1.07 & 5.58 & 27.5 & 11.5 & 3.70 & 0.22 & 55.0 & 298.9 & 403 & -4.3 \\
\hline This study & 28 & 15 & G109-3305 & 4895 & 7.93 & 1.70 & 12.4 & 27.4 & 10.8 & 3.52 & 0.46 & 49.6 & 143.5 & 249 & -7.2 \\
\hline This study & 29 & 19 & Conf. of Gaerqu & 4572 & 7.89 & 2.27 & 30.7 & 23.6 & 11.9 & 21.5 & 0.71 & 49.1 & 155.9 & 296 & -9.0 \\
\hline This study & 30 & 26 & LB Trib. of Buqu & 4778 & 8.09 & 1.47 & 6.64 & 17.8 & 8.02 & 3.91 & 0.48 & 29.1 & 154.2 & 222 & -8.1 \\
\hline This study & 31 & 28 & Source of Buqu & 4992 & 7.87 & 0.80 & 2.19 & 23.2 & 5.02 & 2.33 & 0.06 & 18.3 & 91.8 & 144 & 2.3 \\
\hline \multicolumn{16}{|l|}{ Chumaer He } \\
\hline Zhao et al., 2003 & 32 & - & Chumaer He & - & - & 15.2 & 860 & 112.0 & 54.2 & 1380 & 0.00 & 288.0 & 139.1 & 2848 & 1.6 \\
\hline This study & 33 & 1 & G109-2908 & 4676 & 7.94 & 2.72 & 89.1 & 29.6 & 23.8 & 142.5 & 1.26 & 60.1 & 153.7 & 503 & -4.0 \\
\hline This study & 34 & 2 & Bodongquan & 4589 & 7.42 & 3.47 & 113.5 & 30.8 & 67.1 & 172.8 & 1.40 & 190.4 & 297.0 & 877 & -6.7 \\
\hline This study & 35 & 3 & Xieshui He & 4571 & 7.92 & 2.19 & 24.9 & 18.1 & 10.5 & 36.8 & 2.86 & 25.8 & 103.4 & 224 & -6.5 \\
\hline \multicolumn{16}{|l|}{ Beilu He } \\
\hline Zhao et al., 2003 & 36 & - & South branch of Beilu He & - & - & 26.1 & 1854 & 148.0 & 41.8 & 2910 & 0.00 & 367.7 & 148.8 & 5496 & -2.6 \\
\hline This study & 37 & 5 & G109-3034 & 4583 & 7.72 & 12.4 & 605 & 137.2 & 101.8 & 925.3 & 4.99 & 712.5 & 162.6 & 2662 & 2.3 \\
\hline This study & 38 & 7 & G109-3049 & 4559 & 7.95 & 11.7 & 808 & 84.7 & 30.7 & 1253 & 3.44 & 378.7 & 207.1 & 2778 & -2.4 \\
\hline \multicolumn{16}{|l|}{ Ranchiqu } \\
\hline Zhao et al., 2003 & 39 & - & North branch of Ranchiqu & - & - & 14.4 & 529 & 182.0 & 53.8 & 830.7 & 0.00 & 830.7 & 126.3 & 2566 & 1.7 \\
\hline This study & 40 & 22 & G109-3097 & 4624 & 7.94 & 3.20 & 133.9 & 35.6 & 20.2 & 149.7 & 1.63 & 79.8 & 264.8 & 689 & -9.4 \\
\hline This study & 41 & 23 & G109-3103 & 4595 & 7.73 & 3.55 & 205.9 & 16.7 & 15.9 & 163.5 & 0.43 & 131.2 & 265.2 & 802 & -4.3 \\
\hline This study & 42 & 25 & G109-3111 & 4578 & 7.94 & 7.26 & 196.5 & 28.2 & 57.1 & 237.5 & 0.83 & 200.9 & 271.2 & 999 & -2.9 \\
\hline \multicolumn{16}{|l|}{ Tongtian He } \\
\hline Zhou et al., 2001 & 43 & Q12 & Qidukou & 4223 & 6.50 & 5.93 & 136.1 & 133.5 & 22.1 & 371.9 & - & 99.4 & 114.2 & 883 & 0.4 \\
\hline Zhou et al., 2001 & 44 & Q13 & Bridge of Sewu He & 4186 & 6.70 & 2.24 & 17.7 & 89.0 & 20.9 & 91.4 & - & 19.6 & 214.7 & 456 & 6.4 \\
\hline Zhou et al., 2001 & 45 & Q14 & Conf. of Nieqia He & 4058 & 7.30 & 2.24 & 7.51 & 112.1 & 14.5 & 137.8 & - & 34.6 & 152.7 & 461 & 0.7 \\
\hline Zhou et al., 2001 & 46 & Q15 & Bridge of Tongtian He & 4085 & 7.00 & 6.04 & 140.5 & 94.7 & 22.7 & 208.7 & - & 132.6 & 248.4 & 854 & 0.6 \\
\hline Zhou et al., 2001 & 47 & Q17 & South of Qumalai & 4106 & 6.00 & 4.97 & 117.5 & 95.6 & 29.8 & 194.7 & - & 97.1 & 299.8 & 839 & 0.1 \\
\hline Su and Tang, 1987 & 48 & 1 & Conf. of Ranchiqu & 4444 & 7.90 & 17.8 & 315 & 60.0 & 25.8 & 490.8 & 1.12 & 158.6 & 160.9 & 1230 & -2.5 \\
\hline Su and Tang, 1987 & 49 & 2 & Conf. of Moqu & 4389 & 7.95 & 9.40 & 155.5 & 65.0 & 23.2 & 242.8 & 1.72 & 140.2 & 174.3 & 812 & -3.8 \\
\hline Su and Tang, 1987 & 50 & 3 & Conf. of Beilu He & 4329 & 7.85 & 5.60 & 72.5 & 51.1 & 17.5 & 97.8 & 1.12 & 77.9 & 188.1 & 512 & -2.3 \\
\hline Su and Tang, 1987 & 51 & 4 & Conf. of Keqianqu & 4282 & 8.30 & 5.60 & 111.6 & 49.7 & 19.1 & 170.8 & 1.32 & 85.4 & 162.5 & 606 & -2.2 \\
\hline Su and Tang, 1987 & 52 & 5 & Conf. of Chumaer He & 4216 & 8.10 & 5.20 & 106.4 & 48.9 & 19.2 & 161.9 & 2.08 & 76.0 & 177.5 & 597 & -3.2 \\
\hline Su and Tang, 1987 & 53 & 6 & Sewuqu & 4156 & 8.05 & 4.40 & 82.0 & 46.9 & 17.4 & 121.1 & 0.90 & 64.2 & 175.9 & 513 & -2.3 \\
\hline Su and Tang, 1987 & 54 & 7 & Qumalai & 4180 & 8.00 & 4.40 & 74.2 & 45.9 & 17.0 & 107.9 & 1.32 & 59.5 & 178.9 & 489 & -2.6 \\
\hline Su and Tang, 1987 & 55 & 8 & Dequ & 3869 & 8.31 & 4.50 & 72.5 & 49.7 & 14.8 & 113.8 & 1.20 & 55.7 & 164.1 & 476 & -1.3 \\
\hline Su and Tang, 1987 & 56 & 9 & Zhimenda & 3538 & 8.32 & 4.00 & 72.5 & 48.7 & 15.4 & 112.0 & 1.00 & 59.6 & 163.5 & 477 & -1.7 \\
\hline
\end{tabular}

-: data not available.

a The number we designed.

b The original sample number.

c Conf. = confluence; LB. = left bank; Lo. = Lower; RB. = right bank; Trib. = tributary; Up. = Upper; G109-3xxx = milepost of road G109.

${ }^{\mathrm{d}} \mathrm{NICB}$ (Net Inorganic Charge Balance) $=\left(\mathrm{TZ}^{+}-\mathrm{TZ}^{-}\right) / \mathrm{TZ}^{+} \times 100 \%, \mathrm{TZ}^{+}$(total dissolved cations $)=\mathrm{Na}^{+}+\mathrm{K}^{+}+2 \mathrm{Mg}^{2+}+2 \mathrm{Ca}^{2+}, \mathrm{TZ}^{-}($total dissolved anions $)=\mathrm{Cl}^{-}+2 \mathrm{SO}_{4}^{2-}+\mathrm{HCO}_{3}^{-}$.

\section{References}

Chen, J., 1987. Water Environmental Chemistry. Beijing, China (in Chinese).

Chen, J., Wang, F., Xia, X., Zhang, L., 2002. Major element chemistry of the Changjiang (Yangtze River). Chem. Geol. 187, 231-255

Chen, J., Wang, F., Meybeck, M., He, D., Xia, X., Zhang, L., 2005. Spatial and temporal analysis of water chemistry records (1958-2000) in the Huanghe (Yellow River) basin Glob. Biogeochem. Cycles 19. http://dx.doi.org/10.1029/2004GB002325 GB3016.

Chen, T., Liang, S., Qian, K., Wan, L., 2008. Regularity and cause of vegetation coverage changes in the headwaters of the Changjiang River over the last 22 years. Earth Sci. Front. 15, 323-331 (in Chinese).
Dalai, T., Krishnaswami, S., Sarin, M., 2002. Major ion chemistry in the headwaters of the Yamuna river system: chemical weathering, its temperature dependence and $\mathrm{CO}_{2}$ consumption in the Himalaya. Geochim. Cosmochim. Acta 66, 3397-3416.

Deng, W., 1988. Research on fundamental characteristics of hydrochemistry in the region of the Changijiang River headwater. Sci. Geogr. Sin. 8, 363-370+396 (in Chinese).

Gaillardet, J., Dupré, B., Louvat, P., Allegre, C., 1999. Global silicate weathering and $\mathrm{CO}_{2}$ consumption rates deduced from the chemistry of large rivers. Chem. Geol. 159 3-30.

Galy, A., France-Lanord, C., 1999. Weathering processes in the Ganges-Brahmaputra basin and the riverine alkalinity budget. Chem. Geol. 159, 31-60.

Gao, Q., Tao, Z., 2010. Chemical weathering and chemical runoffs in the seashore granite hills in South China. Sci. China Earth Sci. 53, 1195-1204. 
Gibbs, R.J., 1967. The geochemistry of the Amazon River system: Part I. The factors that control the salinity and the composition and concentration of the suspended solids. Geol. Soc. Am. Bull. 78 (10), 1203-1232.

Gibbs, R.J., 1970. Mechanisms controlling world water chemistry. (New York, NY). Science 170 (3962), 1088

Han, G., Liu, C., 2000. Hydrogeochemistry of Wujiang River water in GuiZhou province. Carsologica Sinica. 19 pp. 35-43 (in Chinese).

Han, G., Liu, C., 2004. Water geochemistry controlled by carbonate dissolution: a study of the river waters draining karst-dominated terrain, Guizhou Province, China. Chem. Geol. 204 (1), 1-21.

Hu, G., Dong, Z., Lu, J., Yan, C., 2011. Driving forces responsible for aeolian desertification in the source region of the Yangtze River from 1975 to 2005. Environ. Earth Sci. 66 (1), 257-263. http://dx.doi.org/10.1007/s12665-011-1235-1.

Huang, X., Sillanpää, M., Gjessing, E., Peräniemi, S., Vogt, R., 2011. Water quality in the southern Tibetan Plateau: chemical evaluation of the Yarlung Tsangpo (Brahmaputra). River Res. Appl. 27, 113-121.

Huh, Y., Tsoi, M.-Y., Zaitsev, A., Edmond, J.M., 1998. The fluvial geochemistry of the rivers of Eastern Siberia: I. Tributaries of the Lena River draining the sedimentary platform of the Siberian Craton. Geochim. Cosmochim. Acta 62, 1657-1676.

Kumarasamy, P., Arthur James, R., Dahms, H., Byeon, C., Ramesh, R., 2014. Multivariate water quality assessment from the Tamiraparani river basin, Southern India. Environ. Earth Sci. 71, 2441-2451.

Li, J., Zhang, J., 2005. Chemical weathering processes and atmospheric $\mathrm{CO}_{2}$ consumption of Huanghe River and Changjiang River basins. Chin. Geogr. Sci. 15, 16-21.

Li, S., Gu, S., Liu, W., Han, H., Zhang, Q., 2008. Water quality in relation to land use and land cover in the upper Han River Basin, China. Catena 75, 216-222.

Li, S., Gu, S., Tan, X., Zhang, Q., 2009. Water quality in the upper Han River basin, China: the impacts of land use/land cover in riparian buffer zone. J. Hazard. Mater. 165, $317-340$

Li, Y., Wang, C., Ma, C., Xu, G., Zhao, X., 2011. Balanced cross-section and crustal shortening analysis in the Tanggula-Tuotuohe Area, Northern Tibet. J. Earth Sci. 22 (1), 1-10

Li, Y., Wang, C., Zhao, X., Yin, A., Ma, C., 2012. Cenozoic thrust system, basin evolution, and uplift of the Tanggula Range in the Tuotuohe region, central Tibet. Gondwana Res. 22 (2), 482-492.

Liang, C., Hou, X., Pan, N., 2011. Spatial and temporal variations of precipitation and runoff in the source region of the Yangtze River. South-North Water Diversion and Water Science \& Technology. 9 pp. 53-59 (in Chinese).

Moon, S., Huh, Y., Qin, J., van Pho, N., 2007. Chemical weathering in the Hong (Red) River basin: rates of silicate weathering and their controlling factors. Geochim. Cosmochim. Acta 71, 1411-1430.

Noh, H., Huh, Y., Qin, J., Ellis, A., 2009. Chemical weathering in the Three Rivers region o Eastern Tibet. Geochim. Cosmochim. Acta 73, 1857-1877.

$\mathrm{Pu}$, J., Wang, P., 1995. Oxygen and hydrogen isotope and hydrological characteristics in the source region of Yangtze River [C]//A Study on Natural Environment in The Source Region of the Yangtze River. 1995. Science Press, Beijing, pp. 46-51 (in Chinese with English abstract).

$\mathrm{Pu}$, J., Wang, P., Huang, C., 1988. Chemical characteristics of glacier ice, snow, water in the headwaters of the Yangtze River. Environ. Sci. 9, 14-19+96 (in Chinese).

Qian, Y., Sun, F., Li, B., Li, S., Zhao, J., 2014. Early Permian-Late Triassic magmatism in the Tuotuohe region of the Qinghai-Tibet Plateau: constrains on the tectonic evolution of the western segment of the Jinshajiang Suture. Acta Geol. Sin. 88 (2), 498-516.

Roy, S., Gaillardet, J., Allegre, C., 1999. Geochemistry of dissolved and suspended loads of the Seine river, France: anthropogenic impact, carbonate and silicate weathering. Geochim. Cosmochim. Acta 63, 1277-1292.

Sarin, M., Krishnaswamy, S., Dilli, K., Somayajulu, B., Moore, W., 1989. Major ion chemistry of Ganga-Brahmaputra river system: weathering processes and fluxes of the Bay of Bengal. Geochim. Cosmochim. Acta 53, 997-1009.
Stallard, R.F., 1980. Major element geochemistry of the Amazon River system[D]. Massachusetts Institute of Technology.

Stallard, R., Edmond, J., 1983. Geochemistry of the Amazon: 2. The influence of geology and weathering environment on the dissolved load. J. Geophys. Res. Oceans (19782012) 88 (C14), 9671-9688.

Stallard, R., Edmond, J., 1987. Geochemistry of the Amazon: 3. Weathering chemistry and limits to dissolved inputs. J. Geophys. Res. Oceans (1978-2012) 92 (C8), 8293-8302.

Su, C., Tang, B., 1987. Hydrochemical characteristics of Tongtian He. Mt. Res. 5, 143-146 (in Chinese)

Sun, G., Deng, W., Shao, Q., Hua, R., 1988. Textual research on the main source of the Changjiang river. Sci. Geogr. Sin. 8, 250-258+296 (in Chinese).

The China Geological Survey, 2004. 1:2 500000 Geological Map of China. China Map Press, Beijing.

Thomas, J., Joseph, S., Thrivikramji, K., Manjusree, T., Arunkumar, K., 2014. Seasonal variation in major ion chemistry of a tropical mountain river, the southern Western Ghats, Kerala, India. Environ. Earth Sci. 71, 2333-2351.

Wang, G., Cheng, G., 2000. Eco-environmental changes and causative analysis in the source regions of the Yangtze and Yellow Rivers, China. Environmentalist 20, 221-232.

Wang, G., Cheng, G., Shen, Y., 2001. Ecological Environment Change and its Comprehensive Protection in Yangtze and Yellow Headwater Region. Lanzhou, China (in Chinese).

Wang, Y., Wu, Q., Tian, L., Niu, F., Tan, L., 2012. Correlation of alpine vegetation degradation and soil nutrient status of permafrost in the source regions of the Yangtze River, China. Environ. Earth Sci. 67 (4), 1215-1223.

Wu, W., Yang, J., Xu, S., Yin, H., 2008. Geochemistry of the headwaters of the Yangtze River, Tongtian He and Jinsha Jiang: silicate weathering and $\mathrm{CO}_{2}$ consumption. Appl. Geochem. 23, 3712-3727.

Wu, W. Xu, S, Yang, J., Yin, H., Tao, X, 2009. Sr fluxes and isotopic compositions in the headwaters of the Yangtze River, Tongtian River, and Jinsha River originating from the Qinghai-Tibet Plateau. Chem. Geol. 260, 63-72.

Xia, X., Yang, Z., Wang, Y., Ji, J., Li, W., Yuan, X., 2008. Major ion chemistry in the Yangtze River. Earth Sci. Front. 15, 194-202 (in Chinese).

Yang, C., 2005. Hydrochemical characteristics of rivers in Qinghai Province. Qinghai Huanjing 15 (3), 110-112 (in Chinese).

Yang, J., Ding Y Chen, R. 2006. Spatial and temporal of variations of alpine vegetation cover in the source regions of the Yangtze and Yellow Rivers of the Tibetan Plateau from 1982 to 2001. Environ. Geol. 50, 313-322.

Zhang, F., 2009. Water chemistry and chemical weathering at Lake Qinghai and Lake Daihai catchments. 19. Nanjing Agricultural University (in Chinese).

Zhang, L., Zhang, S., Dong, W., Wang, L., 1992. The Geochemical Characteristics of Water in Headwater Region of Yangtze River. Beijing, China, pp. 15-18 (in Chinese).

Zhang, L., Song, X., Xia, J., Yuan, R., Zhang, Y., Liu, X., Han, D., 2011. Major element chemistry of the Huai River basin, China. Appl. Geochem. 26, 293-300.

Zhao, J., Geng, D., Peng, J., Liu, C., Dupre, B., Gaillardet, J., Li, W., He, Q., 2003. Origin of major elements and $\mathrm{Sr}$ isotope for river water in Yangtze River source area. Hydrogeol. Eng. Geol. 2, 89-93,98 (in Chinese).

Zhou, C., Dong, S., Wang, G., 2001. Resources characteristics of the major rivers in the source areas of the Changjiang, Huanghe and Lancangjiang. J. Nat. Resour. 16, 493-498 (in Chinese)

Zhou, H., Zhao, X., Tang, Y., Gu, S., Zhou, L., 2005. Alpine grassland degradation and its control in the source region of the Yangtze and Yellow Rivers, China. Grassl. Sci. 51, 191-203. 